\title{
METHODICAL APPROACHES TO BUSINESS PROCESSES REENGINEERING AT MODERN ENTERPRISES
}

\author{
Viktoriia Kyfyak ${ }^{1}$, Yurii Lopatynskyi²
}

\begin{abstract}
The research task is the improvement of scientific principles and development of a methodical approach to the modelling of enterprises' development scenarios that apply business process reengineering in order to increase the level of competitiveness. The urgency of the research. The relevance of further researches is determined by the fact that the practical implementation of scientific approaches in Ukraine has not become popular, and the aspects of business process reengineering have been implemented only fragmentarily. Target setting. The development and discussions of procedural, systemic, and synergetic approaches to enterprise development have determined the concept of business process reengineering. Therefore, the further development of methodical principles for the realization of business process reengineering in the practice of business management is urgent and relevant. Uninvestigated parts of general matters defining. The justification of the expediency of using the tools for business process reengineering through the modelling of the future results at Ukrainian enterprises requires further scientific development. Materials and methods. The historical-evolutionary method was used to investigate the essence and origin of the category of reengineering and to distinguish its main features. By means of analysis and synthesis, the conceptual bases of business processes reengineering are determined. Implementation of complex, systemic, and synergetic approaches as a basis for application of business process reengineering allowed developing a modelling methodology for forecasting scenarios of the level of competitiveness of a business unit. The application of a systematic approach is reflected in the consideration of the impact of external and internal factors on the enterprise, complex factor - in combination of factors with the criteria of the enterprises managing that are able to compete in the world market, as well as the application of method at different levels - macro, meso, and micro. Methods of economic modelling and forecasting were used for forming a model of forecasting of the level of enterprise competitiveness. Results. The main features are segregated and a method for modelling of the results of its implementation is formulated. The algorithm of modelling of development scenario as a result of the application of reengineering is developed. A model for predicting of the level of competitiveness for the Ukrainian economy is constructed as well. Practical implications. The brilliant examples of corporations that received the "second breath" as a result of the introduction and reengineering of processes were General Electric, Toyota and Chrysler, Kodak, Siemens Nixdorf Service, IBM Credit. The proposed methodological approach can be applied by enterprises to predict the level of competitiveness of an enterprise as a result of the introduction of business process reengineering, depending on possible costs and target commodity output. Value/originality. Such a method of forecasting the competitiveness of an enterprise as a result of business process reengineering is important and can be used to predict the level of competitiveness at all levels of management.
\end{abstract}

Key words: business process reengineering, procedural approach, system approach, point of bifurcation, attractor, transurfing.

JEL Classification: M21, L21, P2, L14

\section{Introduction}

The urgency of the research. The relevance of further researches is determined by the fact that the practical implementation of scientific approaches in Ukraine has not become popular, and the aspects of business process reengineering have been implemented only fragmentarily. The experience of using ineffective methodical tools that improve only certain aspects of the management process has proved the necessity for a radical rethinking of the method of transformation and the process of making changes.

\footnotetext{
Corresponding author:

${ }^{1}$ Yuriy Fedkovych Chernivtsi National University, Ukraine.

E-mail: ViktoriaKyfyak@gmail.com

${ }^{2}$ Yuriy Fedkovych Chernivtsi National University, Ukraine.

E-mail: y.lopatynskyi@chnu.edu.ua
} 
The development and discussions of procedural, systemic, and synergetic approaches to enterprise development have determined the concept of business process reengineering. In modern conditions, business process reengineering is not one of the means of crisis management, but a requirement of time for the development of Ukrainian enterprises. Therefore, the further development of methodical principles for the realization of business process reengineering in the practice of business management is urgent and relevant.

Actual scientific researches and issues analysis. In studies of business process reengineering as a methodical approach to changing economic processes, we have to define the sequence of forming the doctrine of reengineering.

The first stage of the development of the concept of business process reengineering was formed by M. Hummer, J. Champy (Hammer, 2006), continuing to consider the conceptual provisions in the work of M. Hammer and L. Hershman (Hammer, 2015). A. Morris, J. Brandon (A. Morris, 1993), H. Harrington (Harrington, 1995) conduct further investigation of business processes reengineering as a management system aimed the consumer (consumer approach).

The analysis of approaches and methods for the estimation of the effectiveness of business processes is carried out in the works (Tiharieva, 2016; Komelina, 2017). Contribution to the development of the method of reengineering applying in the practice of management was carried out by O. Vinogradova (Vynohradova, 2005), L. Taranyuk (Taraniuk, 2008). Methodical approaches to evaluation of the effectiveness of business process reengineering are considered in scientific work directed by N. Abdikeev, which states that in the process of reengineering mainly four sets of tools should be used: process tools, information technology tools, staff tools, and organizational tools (Abdykeev, 2007) and Ang Cheng Leong (Cheng, 2000), who notes that the basic indicators of both individual processes and the whole system are results, efficiency, and flexibility.

The works of Bradley P., Browne J., Jackson S., Jagdev H. (Bradley, 1995) are also devoted to the study of the essence, composition, and functions of business processes. However, the hierarchy of business processes by levels of management during reengineering is not fully explored.

V. Repin and V. Eliferov in (Repyn, 2004) investigated the practical aspects of introducing process approach for the enterprise, focused on modelling and automation of business processes. B. Andersen (Andersen, 2003) considered transformation through a systematic approach to the improvement of business processes and provided effective practical recommendations made by the author for the development of business processes reengineering of enterprises.

The practice of business process reengineering. The main methodologies for managing and establishing business processes used by enterprises are: SADT methodology adapted to the IDEF0 methodology (Cheng, 2000),
ISO 9000-2001 quality management systems, ARIS methodology, MRP (material resource planning for production) that became the result of the development of the IDEF methodology, and others.

The brilliant examples of corporations that received the "second breath" as a result of the introduction and reengineering of processes were General Electric, Toyota and Crysler, Kodak, Siemens Nixdorf Service, IBM Credit.

At the same time, the forecasting of the results of business process reengineering and modelling of enterprise development scenarios require further elaboration in the application of an integrated approach to business processes of enterprises.

Uninvestigated parts of general matters defining. Taking into account the challenges of the turbulent environment of the integration market and the new civilization cycle, justification of the expediency of using the tools for business process reengineering at Ukrainian enterprises requires further scientific development.

The research task is to improve scientific principles and develop a methodical approach to the modelling of enterprises' development scenarios that have applied business process reengineering in order to increase the level of competitiveness.

Materials and methods. The historical-evolutionary method was used to investigate the essence and origin of the category of reengineering and to distinguish its main features. By means of analysis and synthesis, the conceptual bases of business processes reengineering are determined. Implementation of complex, systemic, and synergetic approaches as a basis for the application of business process reengineering allowed developing a modelling methodology for forecasting scenarios of the level of competitiveness of a business unit. The application of a systematic approach is reflected in the consideration of the impact on the enterprise of external and internal factors, complex factor - in combination of factors with the criteria of the enterprises managing that are able to compete in the world market, as well as the application of method at different levels - macro, meso, and micro. Methods of economic modelling and forecasting were used for forming a model of forecasting of the level of enterprises competitiveness.

\section{Interconnection of approaches to business processes reengineering}

In order to outline the practical aspects of the use of business process reengineering, we need to study its in-depth basis. Investigating the essence of the category of reengineering, we find a large number of approaches to its use, but the fundamental principles of its implementation remain unchanged.

The scientific shoots of business process reengineering were formed by the representatives of the procedural approach to the management system (A. Smith, F. Taylor, H. Fayol). The procedural 
approach in management is gaining in popularity; the main advantage of it is the direct orientation towards the customer of products or services. The impetus for the implementation of the procedural approach was a certain exhaustion of competition opportunities due to the reduction of production costs, the application of new production technologies and, therefore, the necessity to reduce the price of the product by reducing administrative costs (Dzoban, 2011). The application of the procedural approach to the operation of enterprises allowed the formation of such a philosophy of economic management, which became the basis for determining the category of "reengineering".

Taking into account that the non-equilibrium and the non-linear by nature of interaction processes become more important in the economy, the presence of positive feedback channels necessitates the introduction of new approaches that take into account such specific properties of a complex system as self-organization (self-reflection), heterarchy, emergency, openness, multilevelness, relativism, cyclic nature of development.

In the concept of "business process reengineering", the postulates of the procedural approach are filled with the content of the systematic approach, according to which the management process is considered as a system of business processes. Moreover, the criterion for division into elements of the system are not the functions of management (as in the functional approach), but a set of relations about the achievement of a certain goal, which, by its turn, corresponds to the goal of the enterprise.

I. Blauberg and E. Yudin make an argumentative reveal of the essence of the system approach (Blauberg, 2007), and specify that the system approach is the direction of the methodology of special-scientific knowledge and social practice, which is based on the study of objects as systems. The system approach facilitates an adequate objective understanding of the problems and the development of an effective reengineering strategy. Most of the proposed definitions of the category "system" are based on the interpretation proposed by the founder of the theory of systems L. Bertalanffy. He defined the system as a complex of interacting elements (Bertalanffy, 1962), which became the basis for the development of many methodological tools.

Another important aspect of the scientifically detailed justification of the concept "system" is that the elements, and now the subsystems, are in relationships and interconnection not only with each other (or one with some others) but also with the environment. This thesis mostly corresponds to the self-organizing systems, and hence to the requirements of the synergistic approach.

N. Grazhevska and L. Tarasevich distinguish the functioning of the economic system as its existence and vital activity in a certain quasi-stationary condition from development as a process of dynamic change of quasistationary conditions (Hrazhevska, 2008; Tarasevych, 1999).
The enterprise, according to a systematic approach, represents a holistic formation that includes economic, social, and organizational aspects of activity; a set of relationships in the middle of an enterprise and the relationship with the external environment in which it develops. The form of connections of these relationships is the structure of the enterprise.

The enterprise consists of many homogeneous relationships, the aggregates of which are subsystems of the enterprise. At the same time, the enterprise is also a subsystem of a particular sector, and the sector is a subsystem of the national economy as a whole. Hence, the criterion for the allocation of a certain set of elements of the object as a system from the totality of all relationships is important. Thus, the enterprise is characterized by the economic, organizational, and social integrity of the relationship. In addition, all elements of the enterprise system are usually aimed at achieving one goal through a system of priorities. So for the interpretation of an enterprise as a system, the number of certain elements (subsystems) is not as important as the system-forming links between these elements that characterize an enterprise as a single economic mechanism.

Therefore, most scholars tend to think that an enterprise is a complex open dynamic system, which is characterized by instability, unbalance, irreversibility, resonance excitation. Such characteristics of the enterprise require from the methods of economic activity the ability to take into account the nonlinearity and adaptability to the laws of forming of the dynamics of enterprise development, which are constantly changing in time, to new data, to market fluctuations (Hizatulin, 2011), which is actual for Ukrainian enterprises.

The lifecycle of complex non-linear open systems, including the business itself and the enterprise as a mean of business implementation, is accompanied by a chain of crises that have a hierarchical structure. Crises are unavoidable in the development of any socio-economic system. The emergence of a crisis signals that the system needs a sharp adjustment, qualitative leap as a necessary condition for further existence. The crucial and critical moment in the development of the economic system, in which it makes the choice of the path, is the point of bifurcation. Bifurcation point is the stage in which there is a "catastrophe" - leaps of development. The higher the level of system organization, the more sensitive is this system to external factors and, therefore, the higher is its activity of influence on the external environment of the system. Those ways or directions, for which the development of the system after the bifurcation point is possible, are different from other due to relative stability, in other words, are more real and are called attractors. An attractor is a relatively stable condition of the system, which attracts many of the lines of development possible after the point of bifurcation (Sukharev, 2010). Therefore, the bifurcation point can be considered as a reference point for implementing business process reengineering. 
Bifurcations have a constructive nature of change. Bifurcations allow making qualitative changes in the system. The catalyst for launching the process of qualitative transformation of the system is the influence of external or internal fluctuations (Dzoban, 2011). Therefore, the catalyst for the implementation of the attractor in the direction of the formation of an effective competitive enterprise is reengineering.

So, understanding the underlying foundations of the systems transformation and the dynamism of the process of their functioning, we will define the objective emerging concept for the implementation of transformational changes - the business process reengineering.

\section{The essence of the category of "business process reengineering"}

The fundamental ideas of the theory and practice of modern business reengineering are described in the work of M. Hammer and J. Champy "Reengineering the Corporation: A Manifesto for Business Revolution”, in which a qualitatively new concept of the internal management of the firm is proposed (Hammer, 2006). The sense of concept consists of a radical revision of the traditional foundations of companies building, their organizational structures, and radical redesign of business processes functioning. The authors in their basic work define reengineering in a concrete way as a fundamental rethinking and radical reorganization of business processes to achieve radical improvements in critically important performance indicators: cost, quality, service, and efficiency (Hammer, 2006), which is of extremely importance to enterprises and organizations of the national economy in the context of providing the level and quality of life, technological security,, and competitiveness.

K. Lam in "A Study of Business Process Reengineering" emphasizes that reengineering is a direction that did not exist before, so it cannot be compared with all our well-known approaches to improving the organization's operations. It is a process of fundamental rethinking and reconstruction of business, embodying new ways of doing things. This is not an "alignment of the organizational structure", not a reorganization, since its object is, above all, processes, rather than organizational units, which are only a means of efficiently conducting these business processes to the ultimate goal. Global automation of the company's activities is not a reengineering as well, because it is one of the necessary prerequisites for the successful conduct of reengineering (Lam, 2010). In this way, the principles of the reengineering philosophy and the principles of the method of change are laid down in the work.

Their point of view is correlated with the opinion of the researcher R. Kimbie, who notes in his work "Business Process Reengineering - When to use it?" that by its nature, reengineering is nothing more than a way to radically improve the company's performance, significantly increase the level of economic potential, as well as an anti-crisis management tool (Kimbie, 2011). Essential is that this is not just one of the ways to successfully develop the entrepreneurial activity, it is a new way of thinking, a look at a company building as an engineering activity, a complete redesign, a fundamental change of the enterprise. R. Kimbie concluded that reengineering is a set of business processes that are aimed at improving the company's performance, which in its turn will lead to competitiveness increasing in a particular market (Kimbie, 2011). We'll agree with it.

Thus, "reengineering" as an economic category was determined by scientists depending on the scope of its application. The substantiated definition of the term "reengineering" was given in the work of L. Shane "Reengineering of Business Processes". It means a decisive, rapid and deep "breakthrough" restructuring of the foundations of the firm's internal organization and management. The specificity of reengineering lies in the fact that the existing narrow specialization and its multiple transfer of responsibility in production and management are reintegrated into through business processes. The responsibility for that processes from the beginning and to the end take on a team of like-minded people who are able to perform a wide range of works (Sheyn, 2008), which outlines the need for effective staffing tools.

Thus, the concept of "reengineering" is based on the formation of a fundamentally new model of management. In addition, the transition to a new model of management is carried out not gradually, but systemic-simultaneously.

In psychology, such an approach has been defined by V. Zeland as "Transurfing” in his work "Transurfing of Reality". Transurfing is a way of concentrating of all efforts on the manifestation of one or another variant of the development of events (Zeland, 2008). Actually, it is not a gradual change in the organizational and functional components of the business unit activity, but simultaneously changing the concept and principles of functioning in the direction of achieving goals. The combination of business process reengineering and transurfing of human resources management provides a systematic approach to making changes. Through the prism of the system approach, both the process of reengineering implementation and the enterprise as the object of transformation are considered.

From the analysis of approaches to the essence of reengineering, we see that its basis is the conceptual perception of the radical transformations of economic systems and the development of modern tools of research of the deep mechanisms of socio-economic transformations. Therefore, it is important to highlight the methodological basis of business process reengineering, which will become a platform for the use of tools in business practice. 
Business process reengineering as a lever of a systemic change in the functioning of a business unit is a synergy of various methodological approaches to transformations, which largely forms reengineering as a multilevel and multifaceted approach to the reformatting of the management process.

Summarizing the foundations of business process reengineering and theories that define different views on the provisions of its application, we may define the main characteristics:

1) Analysis and change of the model of the business operation system. This feature involves the use of tools of economic analysis of business processes using a radically new approach to their implementation, ensuring optimal distribution of existing resources and targeting to the mobilization of new (potential) strategic resources of the company; identification and implementation of key competencies; attraction of investors' capital; increasing of market value and profitability of the company; competitiveness increasing and ensuring the uniqueness of the company in the market, the use of management and implementation of each business process of innovation.

2) Formation of a new model of interaction with the external environment - a strategic vision of the prospects of business development in the existing and prospective markets; the formation of each business process with customer orientation.

3) A clear modelling of the future condition of the enterprise - the definition of business efficiency indicators. Such indicators are the marker of the level of an enterprise competitiveness that we can achieve. Modelling the indicators of the future of business enables to develop and substantiate ways of reformatting the system, besides, is a criterion for the success of business reengineering processes. Note that the values of the resulting indicators should be higher than the existing by $50-100 \%$.

\section{Problems of modelling of business process reengineering}

Taking into account the signs of business process reengineering and the main postulates of the transurfing of reality (the psychological aspect of changes), we note that it is particularly important to model the state of an enterprise competitiveness, as the one that all technological changes and efforts of an employee are oriented on. A. Gizatulin, scientist of economics, in his paper regarding to the study of business process management in the process of reengineering and, in particular, to the question of business process modelling, argues that there are a number of methodological problems, such as scientific contradictions on the following issues (Hizatulin, 2011):

- is it possible to describe the dynamics of subprocesses using linear models?
- is the dynamics of subprocesses a stochastic or deterministic process?

- is it possible to predict the dynamics of business processes, based only on internal or only on external factors?

- which theory more accurately describes the reaction of the enterprise to updating information: the theory of an efficient market or the theory of fractal market?

- is the enterprise an equilibrium and stable system?

- is the enterprise an open or closed system?

- what determines the development of an enterprise: internal contradictions, self-organization or organization through external influence, such as management.

To solve the problems of the results of business process reengineering modelling will help to apply the triad of approaches: process, system, and synergetic.

The disadvantage of previous research in the field of business process reengineering modelling was the incomplete application of the described triad of approaches, according to which the simulation of business process reengineering should be carried out in a combination of indicators of internal business processes (balanced system of indicators) and indicators of the environment (business environment ratings of international organizations).

\section{An integrated approach to business process modelling}

We propose a method for forecasting the competitiveness level of an enterprise, which we can achieve through the use of reengineering techniques. For a good example, let us apply this methodology to the economic system of the country - the economy of Ukraine (which concerns each of average Ukrainian enterprises).

We believe that the most complete combination of the processes of the internal and external environment of the economic system at the macro level is characterized by the Global Competitiveness Index. It is an indicator that annually counts by the World Economic Forum in order to assess the competitiveness of 140 economies, providing an understanding of the factors of their productivity and prosperity. Since the publication of the $2006 / 2007$ report, the report measures competitiveness in 12 areas (quality of institutions, infrastructure, macroeconomic environment, health and primary education, higher education and training, product market efficiency, labour market efficiency, financial markets development, technological development, the size of the domestic market, the level of business development and innovation), summing them up into a single indicator, which reflects the processes of "enter" and "exit" (The Global Competitiveness Report, 2016-2017), namely the environment for the implementation of business processes. For enterprises, the scope of assessment can be replaced by business 
processes that are necessary to achieve a specific goal of enterprise development. Alternatively, you can easily create alternative indicators that will reflect the necessary indicators for the development of the business environment and the criteria for achieving key goals, both at the micro and macro levels.

It is known that the Global Competitiveness Index has a significant impact on the indicators of innovation and the main indicator of the efficiency of the business system at the macro level - GDP per capita, which is, in a way, an indicator of the efficiency of the economic system of the country. Among the many factors influencing the Global Competitiveness Index, we propose to investigate: 1) the impact of the cost factor on research and development (innovation) of the management system at the macro level; 2) influence of the macroeconomic parameter - GDP per capita. So, let's evaluate the influence of the main indicators of these two factors on this index. The statistical data for constructing a model of the dependence of the global competitiveness index on these factors in Ukraine are presented in Table 1.

Table 1

Statistical data for constructing a model

\begin{tabular}{|c|c|c|c|}
\hline Year & $\begin{array}{c}\text { GCI } \\
\text { of } \\
\text { Ukraine* }^{*}\end{array}$ & $\begin{array}{c}\text { Research and } \\
\text { development } \\
\text { costs (\% of } \\
\text { Ukraine's GDP) }\end{array}$ & $\begin{array}{c}\text { GDP per capita } \\
\text { in Ukraine (US dollar } \\
\text { according to course } \\
\text { in a certain period) }\end{array}$ \\
\hline 2005 & 84 & 1,03202 & 6452,096195 \\
\hline 2006 & 78 & 0,94934 & 7184,203287 \\
\hline 2007 & 73 & 0,85288 & 8005,69176 \\
\hline 2008 & 72 & 0,84649 & 8395,812545 \\
\hline 2009 & 82 & 0,85676 & 7239,624226 \\
\hline 2010 & 87 & 0,83295 & 7666,219577 \\
\hline 2011 & 82 & 0,7378 & 8281,867126 \\
\hline 2012 & 73 & 0,75418 & 8475,471746 \\
\hline 2013 & 84 & 0,75926 & 8629,676994 \\
\hline 2014 & 76 & 0,64908 & 8683,640842 \\
\hline 2015 & 79 & 0,61742 & 7948,142096 \\
\hline 2016 & 81 & 0,816231151 & 8271,779979 \\
\hline
\end{tabular}

* http://reports.weforum.org

** http://www.worldbank.org/uk/country/ukraine

The performed calculations showed that given dependence the most appropriately describes the model of the form:

$$
G C I=125.65-12.66 \text { In }-0.0046 Y_{p c} \text {, }
$$

where $G C I$ - the global competitiveness index, In research and development costs (innovation) and $Y_{p c}-$ GDP per capita.

Checking the model. An important point in the modelling process is the objective determination of the quality of the model. Since model estimations are random variables, a set of statistical criteria is used to determine their quality. Quite often, the quality of estimations of forecasts is determined only with the root mean square (rms) error. However, this value depends on the scale of the data, and therefore, this characteristic is not enough to analyse the quality of the forecast. In-depth evaluation of the quality of the model is achieved through the use of criteria that give relative quality assessments, for example, the Theil index. The advantage of their use is that they do not depend on the scale of the data. The Theil index is calculated by the expressions:

$$
T=\frac{\sqrt{\sum_{i=1}^{n}\left(\hat{y}_{i}-y_{i}\right)^{2} / n}}{\sqrt{\frac{1}{n} \sum_{i=1}^{n} y_{i}^{2}}+\sqrt{\frac{1}{n} \sum_{i=1}^{n} \hat{y}_{i}^{2}}},
$$

where $n$ - the horizon of the steps of forecasting; $y_{i}-$ actual data values; $\hat{y}_{i}$ - estimations of forecasts.

The Theil index $T$ is an important indicator of model quality and forecast. According to the definition, the Theil index lies within $0 \leq T \leq 10$. When $T \rightarrow 0$, these estimations of forecasts approach the actual values of the series and the model have a high degree of adequacy. So $\mathrm{T}$ makes it possible to establish the suitability of the model (method) for estimating the forecast as a basement. In many cases, better prediction results can be achieved by averaging (or combining by weighting coefficients) estimations of forecasts obtained by different methods.

The Theil index for the constructed model is 0.026, which confirms the adequacy of the model. Consequently, the model can be used for further analysis.

Based on model (1), a sort of graphs of the Global Competitiveness Index for the Ukrainian economy can be built. To do this, we fix this index at the level 55, 50, $45,40,35,30$. The plural of curves will have the form (Figure 1):

$$
\begin{array}{cl}
Y_{p c}=\frac{70.65-12.66 I n}{0.0046}, & \text { if } G C I=55, \\
Y_{p c}=\frac{75.65-12.66 I n}{0.0046}, & \text { if } G C I=50, \\
Y_{p c}=\frac{80.65-12.66 I n}{0.0046}, & \text { if } G C I=45, \\
Y_{p c}=\frac{85.65-12.66 I n}{0.0046}, & \text { if } G C I=40, \\
Y_{p c}=\frac{90.65-12.66 I n}{0.0046}, & \text { if } G C I=35, \\
Y_{p c}=\frac{95.65-12.66 I n}{0.0046}, & \text { if } G C I=30 .
\end{array}
$$

The family of graphs of the Global Competitiveness Index allows us to predict the level of competitiveness of the country's economy, with a known amount of research and development costs (innovation) and GDP per capita.

At the enterprise level, we can simulate the situation through a system of business process changes based on the known value of the cost of reengineering and the target value of gross output. 


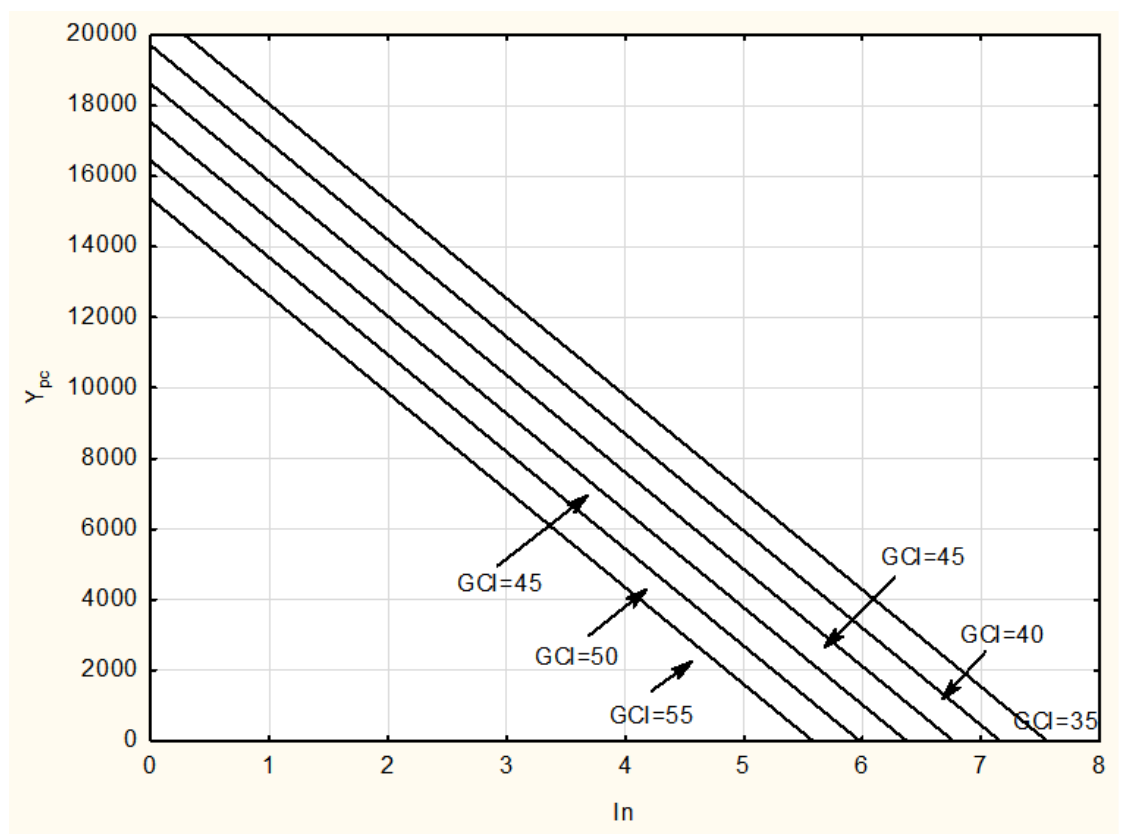

Figure 1. Families of the graphs of the Global Competitiveness Index of Ukraine

We believe that such a method of forecasting of enterprise competitiveness as a result of business processes reengineering is important and can be used to predict the level of competitiveness at all levels of management.

\section{Conclusions}

1. It has been determined that business process reengineering is a form of evolution of procedural, synergetic and systemic approaches taking into account some aspects of psychological transformation transurfing.

2. The reengineering of business processes becomes of particular importance in the practical activity of enterprises in an unstable environment and under conditions of nonlinear development of the economic unit as a system. The bifurcation point for the business system is the best time to apply the business process reengineering approach. An attractor determines the priorities of transformation taking into account the methodological approaches of reengineering.

3. Reengineering of business processes is a mechanism for organizational restructuring and technical reform of the company, for the maximum automation of business operations and radically different approaches to the organization of work, which leads to a significant increase in the competitiveness of the enterprise.

4. The process of reengineering must meet the following requirements: change the system of operation of the enterprise, the formation of a new model of interaction with the environment, a clear modelling of the future state of the enterprise.

5. Using the integrated approach of the interaction of external and internal factors of the development of the enterprise, the method of forecasting of competitiveness level of the enterprise as a result of the application of business process reengineering is offered. The methodology has been tested for scenario modelling of the Ukrainian economy's competitiveness. In the methodology, it is suggested to use the estimation of 12 spheres (according to the method of calculation of the Global Competitiveness Index) and the quality criteria of the obtained model (the Theil model).

Developed approach to the modelling of the result of business process reengineering allowed taking into account the influence of external and internal factors.

The proposed methodological approach can be applied by enterprises to predict the level of competitiveness of an enterprise as a result of the introduction of business process reengineering, depending on possible costs and target commodity output.

\section{References:}

Khammer, M., Champi, Dzh. (2006). Reinzhiniring korporatsii: manifest revolyutsii v biznese [Reengineering the Corporation: A Manifesto for Business Revolution]. Moskva: Mann. (in Russian)

Khammer, M., Khershman, L. (2015). Bystree, luchshe, deshevle. Devyat metodov reinzhiniringa biznes-protsessov [Faster, better, cheaper. Nine methods of reengineering of business processes]. Moskva: Alpina Pablisher. (in Russian) 
Morris-Joel Brandon, D. (1993). Reengineering your business. New York: McGraw Hill, Inc.

Harrington, H. J., Harrington, J. S. (1995). Total improvement management: the next generation in performance improvement. New York: McGraw Hill, Inc.

Tigharjeva, V. A., Stankevych, I. V. (2016). Analiz isnujuchykh pidkhodiv ta metodiv ocinjuvannja biznesprocesiv pidpryjemstv ta orghanizacij [Analysis of existing approaches and methods of evaluation business processes of enterprises and organizations]. Visnyk Kremenchucjkogho nacionaljnogho universytetu imeni Mykhajla Ostroghradsjkogho, vol. 3(1), pp. 113-122. (in Ukrainian)

Komelina, O. V., Stepanenko, Je. V. (2017). Osoblyvosti zastosuvannja reinzhynirynghu biznes-procesiv na suchasnomu pidpryjemstvi [Features of application of reengineering of business processes on modern enterprise]. Skhidna Jevropa: ekonomika, biznes ta upravlinnja, vol. 6(11), pp. 124-129. (in Ukrainian)

Vynohradova, O. V. (2005). Reinzhyniryngh biznes-procesiv torghoveljnykh pidpryjemstv [Business process reengineering in modern management]. Donecjk: DonDUET, Ukraine. (in Ukrainian)

Taranjuk, L. M. (2008). Ekonomichni osnovy reinzhynirynghu biznes-procesiv [The economic fundamentals of business process reengineering]. Sumy: Mrija-1, Ukraine. (in Ukrainian)

Abdikeev, N. M., Danko, T. P., Ildemenov, S. V., Kiselev, A. D. (2007). Reinzhiniring biznes-protsessov [Reengineering of business processes]. Moskva: Eksmo. (in Russian)

Leong Ang Cheng, (2000) IDEF*. A comprehensive Modelling Methodology for the Development of Manufacturing Enterprise Systems. Singapore Institute of Manufactoring Technology.

Bradley, P., Browne, J., Jackson, S., Jagdev, H. (1995). Business process re-engineering (BPR) - a study of the software tools currently available. Computers in Industry - Special issue: CIM in the extended enterprise, vol. 25, issue 3, pp. 309-330.

Repin, V. V., Eliferov, V. H. (2004). Protsessnyy podkhod k upravleniyu. Modelirovanie biznes-protsessov [The process approach to business process modeling]. Moskva: RIA Standarty i kachestvo, Russia (in Russian)

Andersen, B. (2003). Biznes-protsessy. Instrumenty sovershenstvovaniia [Business processes. Tools perfection]. Moskva: RIA Standarty i kachestvo, Russia. (in Russian)

Dzjobanj, O. P. (2011). Suchasna socialjna syneretyka: do pytannja pro vyznachennja konceptualjnykh osnov [Modern social synergetics: to the question of definition of conceptual foundations]. Retrieved from: http://dspace.nlu.edu.ua/ bitstream/123456789/3537/1/Dzoban_3.pdf. (accessed 14.06.2018) (in Ukrainian)

Blaubergh, I. V. (2007). Stanovlennja i sutnistj systemnogho pidkhodu [Formation and the essence of the system approach]. Moskva: Nauka. (in Russian)

Bertalanffy, L. (1968). General System Theory: Foundations, Development, Applications. New York: George Braziller. Ghrazhevsjka, N. I. (2008). Ekonomichni systemy epokhy ghlobaljnykh zmin [The economic system of the era of global change]. Kyjiv: Znannja, Ukraine. (in Ukrainian)

Tarasevich, L. S., Galperin, P. I., Grebennikov, V. M., Leusskiy, A. Y. (1999). Makroekonomika [Macroeconomics]. Sank-Peterburg: SPbHUEF. (in Russian)

Ghizatulin, A. M. (2011). Metodologhichni problemy matematychnogho modeljuvannja biznes-procesiv [Methodological problems of mathematical modeling of business processes], Zbirnyk DonNTU, vol. 2, pp. 20-27. (in Ukrainian)

Sukharev, O. S., Kuryanov, A. M. (2011). Sinergetika investitsiy. [Synergetics of investments]. Moskva: Finansy i statistika; INFRA-M. (in Russian)

Lam, K. (2010). A Study of Business Process Reengineering. Retrieved from: http://www.doc.ic.ac.uk/ nd/ surprise_95/journal/vol2/tmkl/article2.html (accessed 12.06.2018)

Kimbie, $\bar{R}$. (2011). Business Process Reengineerinng - When to use it? Retrieved from: http://ezinearticles.com/?BusinessProcessReengineering-When-to-Use-it\&id=6133794.html (accessed March 3, 2014)

Sheyn, L. (2002). Reinzhiniring biznes-protsessov: modnoe lekarstvo? [Business process reengineering: fashionable medicine?]. Upravlenie kompaniey, vol. 6, pp. 68-76. (in Russian)

Zeland, V. (2008). Transerfing realnosti. Stupen I: Prostranstvo variantov. [Reality Transurfing 1: The Space of Variations]. Sank-Peterburg: IG «Ves». (in Russian)

World Economic Forum, Klaus Schwab (2017). The Global Competitiveness Report 2016-2017. Geneva.

Prysenko, H. V., Ravikovych, Ye. I. (2005). Proghnozuvannja socialjno-ekonomichnykh procesiv [Prediction of socioeconomic processes]. Kyiv: KNEU, Ukraine. (in Ukrainian) 